\title{
Streptococcus castoreus sp. nov., isolated from a beaver (Castor fiber)
}

\author{
Paul A. Lawson, ${ }^{1}$ Geoffrey Foster, ${ }^{2}$ Enevold Falsen, ${ }^{3}$ \\ Susanne J. Markopoulos ${ }^{3}$ and Matthew D. Collins ${ }^{1}$ \\ ${ }^{1}$ School of Food Biosciences, University of Reading, Whiteknights, Reading RG6 6AP, UK \\ 2SAC Veterinary Services, Inverness, UK \\ ${ }^{3}$ Culture Collection, Department of Clinical Bacteriology, University of Göteborg, Sweden
}

\begin{abstract}
A previously undescribed, Gram-positive, catalase-negative, Streptococcus-like organism originating from a European beaver (Castor fiber) was subjected to a taxonomic study. The organism displayed $\beta$-haemolytic activity and gave a positive reaction with Lancefield group $\mathrm{A}$ antisera. Based on the results of biochemical testing, the organism was tentatively identified as a member of the genus Streptococcus, but it did not correspond phenotypically to any recognized species of this genus. Comparative 16S rRNA gene sequencing studies confirmed this assignment, with the bacterium forming a hitherto unknown subline within the genus. Sequence divergence values of greater than $3 \%$ from other reference streptococcal species, however, demonstrated that the unidentified coccus-shaped organism represents a hitherto unknown species. Based on phenotypic and molecular phylogenetic evidence, it is therefore proposed that the unknown organism from a beaver be classified as a novel species, Streptococcus castoreus sp. nov. The type strain is M605815/03/2 ${ }^{\top}$ (=CCUG $48115^{\top}=$ CIP $108205^{\top}$ ).
\end{abstract}

The genus Streptococcus contains the largest number of low-G + C-content, Gram-positive bacteria and encompasses a diverse collection of facultatively anaerobic, catalase-negative, chain-forming, coccus-shaped organisms. Currently the genus comprises more than 60 species, a high proportion of which have been described relatively recently, in the main because of the use of much-improved phenotypic and molecular identification methods (Facklam, 2002). However, despite this rapid increase in the number of recognized streptococcal species, it is evident that much novel diversity remains to be discovered, especially from animal sources (e.g. Collins et al., 2002; Devriese et al., 1997, 1999; Rurangirwa et al., 2000; Vela et al., 2002). In the course of an ongoing study exploring the diversity of taxonomically problematic catalase-negative cocci from animal sources, we have characterized a $\beta$-haemolytic organism from a beaver that, although phenotypically consistent with the genus Streptococcus, does not appear to correspond to any recognized species. Based on the presented findings, we describe a novel species of the genus Streptococcus, Streptococcus castoreus sp. nov.

Bacterial strain M605815/03/2 ${ }^{\mathrm{T}}$ (=CCUG $48115^{\mathrm{T}}$ ) was recovered from a European beaver (Castor fiber) carcass

Published online ahead of print on 29 October 2004 as DOI 10.1099/ ijs.0.63433-0.

The GenBank/EMBL/DDBJ accession number for the $16 \mathrm{~S}$ rRNA gene sequence of strain CCUG $48115^{\top}$ is AJ606047. submitted by a wildlife park that had multiple bite wounds received from other beavers housed in the same compound. The unknown coccus-shaped organism was cultured in confluent growth with a Neisseria species and Morganella morganii from a wound. The same organism was recovered in pure culture from the spleen and together with Escherichia coli from the liver. The unidentified coccus was cultured on Columbia blood agar base supplemented with $5 \%$ horse blood at $37^{\circ} \mathrm{C}$, under anaerobic conditions. Lancefield serological grouping was determined by using the Streptex (Remell Europe Ltd) test system. The organism was biochemically characterized using the API Rapid ID 32Strep, API 20Strep and API ZYM test systems according to the manufacturer's instructions (API bioMérieux). The G $+\mathrm{C}$ content of the DNA was determined by HPLC according to Mesbah et al. (1989). For phylogenetic analysis, 16S rRNA genes were amplified by PCR and directly sequenced using a Taq Dye-Deoxy terminator cycle sequencing kit (Applied Biosystems) and an automatic DNA sequencer (model 373A; Applied Biosystems). The closest known relatives of the new isolate were determined by performing GenBank/ EMBL database searches. These sequences and those of other known related strains were retrieved from GenBank/ EMBL and aligned with the newly determined sequence using the program DNATOOLS (Rasmussen, 1995). The resulting multiple sequence alignment had approximately 100 bases at the $5^{\prime}$ end of the rRNA gene sequence omitted from further analysis (because of alignment uncertainties as a result of the highly variable region V1) using the 
program GENEDOC (Nicholas et al., 1997). A phylogenetic tree was constructed according to the neighbour-joining method (Saitou \& Nei, 1987) with the programs DNATOOLS and TREEVIEW (Page, 1996); the stability of the groupings was estimated by bootstrap analysis (1000 replications) using the same programs.

Cells of strain CCUG $48115^{\mathrm{T}}$ stained Gram-positive and formed pairs or chain cellular arrangements. The bacterium was facultatively anaerobic, but grew best under anaerobic conditions. Growth was stimulated by rich medium and $\mathrm{CO}_{2}$, but was not obligately capnophilic. There was no growth on MRS at $37^{\circ} \mathrm{C}$ in air, but growth was observed on MRS in $\mathrm{CO}_{2}$ and in a microaerophilic atmosphere. Growth on chocolate medium was superior to growth on blood agar. The organism displayed $\beta$-haemolytic activity and gave a strong reaction in Streptex with Lancefield group A antisera. It was facultatively anaerobic and catalase-negative. Using the API 20Strep system, the organism produced acid from starch, but not from any of the other carbohydrates in this test gallery. The organism hydrolysed aesculin but failed to hydrolyse hippurate, and it was Voges-Proskauer negative. It displayed activity for arginine dihydrolase, alkaline phosphatase, $\beta$-glucuronidase and leucine arylamidase, but all other enzyme tests included in this system were negative. Using the API Rapid ID 32Strep test system, the organism produced acid from maltose, methyl $\beta$-D-glucopyranoside, pullulan and sucrose. Activity was detected for arginine dihydrolase, alkaline phosphatase, alanine phenylalanine proline arylamidase, $\beta$-glucosidase and $\beta$-glucuronidase; $\beta$-mannosidase activity was variable. Using the API ZYM kit, positive reactions were obtained for acid phosphatase, alkaline phosphatase, leucine arylamidase, phosphoamidase and $\beta$-glucuronidase. All other enzyme tests in the API ZYM system were negative. The morphological and general biochemical characteristics of the unidentified coccus were consistent with its tentative identification as a member of the genus Streptococcus, but it did not correspond to any recognized species.

To investigate the phylogenetic affinities of strain CCUG $48115^{\mathrm{T}}$, its $16 \mathrm{~S}$ rRNA gene sequence was determined and subjected to a comparative analysis. The almost complete gene sequence ( $>1400$ bases) of the unidentified organism was determined and searches of the GenBank database revealed species of the genus Streptococcus as the nearest phylogenetic relatives. Highest $16 \mathrm{~S}$ rRNA gene sequence similarities were shown with species of the 'pyogenic subgroup' of streptococci (data not shown). A dendrogram depicting the position of the unknown coccus within the 'pyogenic subgroup' is shown in Fig. 1. The unknown organism formed a distinct subline within this group, clustering loosely with Streptococcus porcinus.

It is clear from comparative $16 \mathrm{~S}$ rRNA gene sequence analysis that the unidentified organism represents a hitherto unknown species within the 'pyogenic streptococcal subgroup' of organisms. Phylogenetically it forms a distinct subline, and, although treeing analysis revealed that it

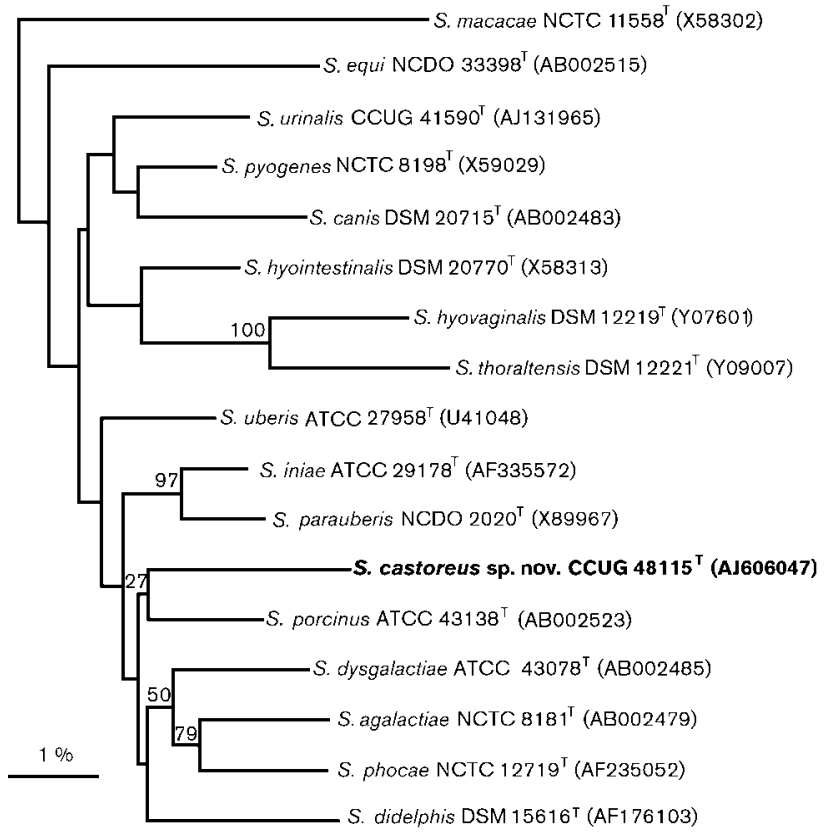

Fig. 1. Unrooted tree based on $16 \mathrm{~S}$ rRNA gene sequence analysis showing the phylogenetic relationships of Streptococcus castoreus sp. nov. and other 'pyogenic subgroup' species. Bar, $1 \%$ sequence divergence.

exhibited an affinity with $S$. porcinus, bootstrap resampling showed this association was not statistically significant (Fig. 1). Strain CCUG $48115^{\mathrm{T}}$ displayed relatively high $16 \mathrm{~S}$ rRNA gene sequence divergence values (greater than $3 \%$ ) from other recognized species within the 'pyogenic subgroup'. For example, highest sequence similarities were shown with S. porcinus $(96.4 \%)$ and Streptococcus iniae $(96 \cdot 2 \%)$, with other 'pyogenic' streptococcal species showing substantially lower similarity values. Both tree topology considerations and divergence values greater than $3 \%$ are strongly indicative that strain CCUG $48115^{\mathrm{T}}$ represents a novel species within the 'pyogenic subgroup'. Support for its distinctiveness is also evident from phenotypic criteria. The unknown bacterium resembles Streptococcus pyogenes in giving a positive reaction with Lancefield group A antisera and in its $\beta$-haemolytic activity. However, strain CCUG $48115^{\mathrm{T}}$ can be readily distinguished from S. pyogenes based on it forming acid from trehalose, its positive $\beta$-glucuronidase reaction and its negative pyrrolidonyl arylamidase reaction. The unknown bacterium can also be distinguished biochemically from other $\beta$-haemolytic streptococcal species. In particular, the production of API Rapid ID 32Strep and API 20Strep numerical profiles 35002041110 and 4461005, respectively, serves to distinguish the novel bacterium from all other recognized streptococcal species. Therefore, based on both phenotypic and phylogenetic criteria, we suggest that the unknown bacterium isolated from a dead beaver merits assignment to a novel species within the genus Streptococcus, for which the name Streptococcus castoreus sp. nov. is proposed. Tests 
Table 1. Tests that are useful in distinguishing Streptococcus castoreus sp. nov. from some related $\beta$-haemolytic streptococci

Taxa: 1, S. castoreus; 2, S. agalactiae; 3, S. canis; 4, S. didelphis; 5, S. iniae; 6, S. phocae; 7, S. porcinus; 8, S. equi subsp. equi; 9, S. equi subsp. zooepidemicus; 10, S. pyogenes. Information on Lancefield antigens and haemolytic reactions is from Facklam (2002); biochemical results were obtained from the API Rapid ID 32Strep test system (present study). +, Positive; -, negative; V, variable.

\begin{tabular}{|c|c|c|c|c|c|c|c|c|c|c|}
\hline Characteristic & 1 & 2 & 3 & 4 & 5 & 6 & 7 & 8 & 9 & 10 \\
\hline \multicolumn{11}{|l|}{ Acid from: } \\
\hline Cyclodextrin & - & - & - & - & $\mathrm{V}$ & - & - & $\mathrm{V}$ & + & $\mathrm{V}$ \\
\hline Glycogen & - & - & - & - & + & $\mathrm{V}$ & - & + & + & $\mathrm{V}$ \\
\hline Mannitol & - & - & - & - & $\mathrm{V}$ & - & + & - & - & - \\
\hline Ribose & - & + & + & + & + & - & + & - & $\mathrm{V}$ & - \\
\hline Sorbitol & - & - & - & - & - & - & + & - & + & - \\
\hline Sucrose & + & + & + & + & + & - & + & + & + & + \\
\hline Trehalose & - & $\mathrm{V}$ & $\mathrm{V}$ & + & + & - & + & - & $\mathrm{V}$ & + \\
\hline \multicolumn{11}{|l|}{ Production of: } \\
\hline
\end{tabular}

useful in distinguishing $S$. castoreus from other closely related $\beta$-haemolytic streptococcal species are given in Table 1.

\section{Description of Streptococcus castoreus sp. nov.}

Streptococcus castoreus (cas.to're.us. L. masc. adj. castoreus pertaining to a beaver, from which the bacterium was originally isolated).

Cells stain Gram-positive and are cocci that occur in pairs or short chains. Non-spore-forming. Facultatively anaerobic, but grows best under anaerobic conditions. Growth is stimulated by rich medium and $\mathrm{CO}_{2}$, but is not obligately capnophilic. No growth on MRS at $37^{\circ} \mathrm{C}$ in air, but there is growth on MRS in $\mathrm{CO}_{2}$ and in a microaerophilic atmosphere. Growth on chocolate medium is superior to growth on blood agar. Colonies are $\beta$-haemolytic and $0.5 \mathrm{~mm}$ in diameter after $24 \mathrm{~h}$ of incubation on horse blood agar. Produces a strong reaction in Oxoid Strep latex with Lancefield group A antisera. Facultatively anaerobic and catalase-negative. Using API test kits, acid is produced from starch, maltose, methyl $\beta$-D-glucopyranoside, pullulan and sucrose. Acid is not produced from L-arabinose, Darabitol, cyclodextrin, glycogen, inulin, lactose, mannitol, melezitose, melibiose, raffinose, sorbitol, tagatose or trehalose. Aesculin is hydrolysed but hippurate is not. Activity is detected for arginine dihydrolase, acid phosphatase, alkaline phosphatase, alanine phenylalanine proline arylamidase, leucine arylamidase, phosphoamidase, $\beta$-glucosidase and $\beta$-glucuronidase; activity for $\beta$-mannosidase is variable. Activity is not detected for esterase $C 4$, ester lipase C8, lipase C14, chymotrypsin, cystine arylamidase, $\alpha$-fucosidase, $\alpha$-galactosidase, $\beta$-galactosidase, $\alpha$-glucosidase, glycyl tryptophan arylamidase, $\alpha$-mannosidase, pyroglutamic acid arylamidase, $N$-acetyl- $\beta$-glucosaminidase, trypsin, valine arylamidase or urease. Voges-Proskauer test is negative. The DNA G $+\mathrm{C}$ content is $37 \cdot 4 \mathrm{~mol} \%$.

The type strain, M605815/03/2 ${ }^{\mathrm{T}}$ (=CCUG $48115^{\mathrm{T}}=\mathrm{CIP}$ $108205^{\mathrm{T}}$ ), was isolated from a European beaver (Castor fiber).

\section{Acknowledgements}

We acknowledge the help of Kent Molin, Elisabeth Inganäs and Maria Ohlén in performing phenotypic analyses. We are also grateful to Hans Trüper for advice on the species name. SAC Veterinary Services is supported by the Scottish Office, Environment and Fisheries Department.

\section{References}

Collins, M. D., Hutson, R. A., Falsen, E., Inganäs, E. \& Bisgaard, M. (2002). Streptococcus gallinaceus sp. nov., from chickens. Int J Syst Evol Microbiol 52, 1161-1164.

Devriese, L. A., Pot, B., Vandamme, P., Kersters, K., Collins, M. D., Alvarez, N., Haesebrouck, F. \& Hommez, J. (1997). Streptococcus hyovaginalis sp. nov. and Streptococcus thoraltensis sp. nov., from the genital tract of sows. Int J Syst Bacteriol 47, 1073-1077.

Devriese, L. A., Vandamme, P., Collins, M. D., Alvarez, N., Pot, B., Hommez, J., Butaye, P. \& Haesebrouck, F. (1999). Streptococcus pluranimalium sp. nov., from cattle and other animals. Int J Syst Bacteriol 49, 1221-1226.

Facklam, R. R. (2002). What happened to the streptococci: overview of taxonomic and nomenclatural changes. Clin Microbiol Rev 15, 613-630. 
Mesbah, M., Premachandran, U. \& Whitman, W. B. (1989). Precise measurement of the $\mathrm{G}+\mathrm{C}$ content of deoxyribonucleic acid by high-performance liquid chromatography. Int J Syst Bacteriol 39, 159-167.

Nicholas, K. B., Nicholas, H. B., Jr \& Deerfield, D. W. (1997). GENEDOC: analysis and visualisation of genetic variation. EMBNEW News 4, 14.

Page, R. D. M. (1996). TREEVIEW: an application to display phylogenetic trees on personal computer. Comput Appl Biosci 12, 357-358.

Rasmussen, S. W. (1995). DNATOOLS, a software package for DNA sequence analysis. Copenhagen: Carlsberg Laboratory.
Rurangirwa, F. R., Teitzel, C. A., Cui, J., French, D. M., McDonough, P. L. \& Besser, T. (2000). Streptococcus didelphis sp. nov., a streptococcus with marked catalase activity isolated from opossums (Didelphis virginiana) with suppurative dermatitis and liver fibrosis. Int J Syst Evol Microbiol 50, 759-765.

Saitou, N. \& Nei, M. (1987). The neighbor-joining method: a new method for reconstructing phylogenetic trees. Mol Biol Evol 4, 406-425.

Vela, A. I., Fernández, E., Lawson, P. A., Latre, M. V., Falsen, E., Domínguez, L., Collins, M. D. \& Fernández-Garayzábal, J. F. (2002). Streptococcus entericus sp. nov., isolated from cattle intestine. Int J Syst Evol Microbiol 52, 665-669. 